\title{
Tools for the Promotion of International Trade in the Eurasian Economic Union Member States: the Case of Kyrgyzstan
}

\author{
K.A. Azhekbarov ${ }^{\mathrm{a}}$, A.V. Bondarenko ${ }^{\mathrm{b}}$, A.Y. Kozhankov \\ ${ }^{a}$ Ryskulbekov Kyrgyz Economic University, Bishkek, Kyrgyz Republic; \\ b, c Moscow State Institute of International Relations (University) of the Ministry of Foreign Affairs of Russia, \\ Moscow, Russia; \\ 'Russian Customs Academy, Lyubertsy, Russia \\ ${ }^{\text {a }}$ https://orcid.org/0000-0002-0952-5124; b https://orcid.org/0000-0003-1996-0514; \\ c https://orcid.org/0000-0003-0504-2333
}

\begin{abstract}
The article presents the results of the United Nations Economic Commission for Europe project in Kyrgyzstan: "Reinforcement of national capacity of the trade-support institutions". Based on these results, the further actions on international trade promotion have been proposed. One of them is a capacity building of state bodies and business in the area of international standards and best practices. It is important to increase the availability of information on the rules and requirements of the government regulation of external economic activity, both within the country and in the partner countries. It is required to provide systematic work with state bodies and businesses in all regions of the Kyrgyz Republic. For this, a permanent Regional Training Centre must be created. The Ryskulbekov Kyrgyz Economic University will become the base for this centre. In close cooperation with the leading universities of the Eurasian Economic Union member states and the countries of Central Asia, it is advisable to expand the region the training centre activity. It is also necessary to envisage the possibility to organise a network model of training programs of the training centre in all countries of the region.

Keywords: trade facilitation; international standards; cross-border paperless trade; Eurasian Economic Union; international trade; Regional Training Centre
\end{abstract}

For citation: Azhekbarov K.A., Bondarenko A.V., Kozhankov A.Y. Tools for the promotion of international trade in the Eurasian Economic Union Member States: the case of Kyrgyzstan. Finansy: teoriya i praktika= Finance: Theory and Practice. 2018;22(6):157-162. DOI: 10.26794/2587-56712018-22-6-157-162

\section{Инструменты содействия международной торговле в государствах - членах Евразийского экономического союза на примере Кыргызстана}

\author{
К.А. Ажекбаров ${ }^{a}$, А.В. Бондаренко ${ }^{\text {, А. Ю. Кожанков }}$ \\ а Кыргызский экономический университет им. М. Рыскулбекова, Бишкек, Кыргызская Республика; \\ b, Московский государственный институт международных отношений (Университет) МИД России, Москва, Россия; \\ с Российская таможенная академия, Люберцы, Россия \\ ${ }^{\text {a } h t t p s: / / o r c i d . o r g / 0000-0002-0952-5124 ; ~}{ }^{b}$ https://orcid.org/0000-0003-1996-0514; \\ c https://orcid.org/0000-0003-0504-2333
}

\begin{abstract}
АННОТАЦИЯ
Статья представляет результаты проекта Европейской экономической комиссии ООН в Кыргызстане: «Укрепление национального потенциала институтов поддержки торговли». На их основании предложены дальнейшие шаги по содействию международной торговли. Среди них: наращивание потенциала государственных органов и бизнеса в области международных стандартов и лучших практик. Важно повышать доступность информации о правилах и требованиях государственного регулирования внешнеэкономической деятельности как внутри страны, так и в странах-партнерах. Требуется проведение системной работы с госорганами и бизнесом во всех регионах Кыр-
\end{abstract}


гызской Республики. Для этого необходимо наличие постоянно действующего Регионального учебного центра. Его базой станет Кыргызский экономический университет им. М. Рыскулбекова. В тесном взаимодействии с ведущими университетами государств - членов Евразийского экономического союза и стран Центральной Азии целесообразно расширять регион деятельности учебного центра. Необходимо предусмотреть возможность организации сетевой модели обучения по актуальным учебным программам во всех странах региона.

Ключевые слова: упрощение процедур торговли; международные стандарты; трансграничная безбумажная торговля; Евразийский экономический союз; внешняя торговля; региональный учебный центр

Для цитирования: Ажекбаров К.А., Бондаренко А.В., Кожанков А.Ю. Инструменты содействия международной торговле в государствах членах Евразийского экономического союза на примере Кыргызстана. Финансы: теория и практика. 2018;22(6):157-162. DOI: 10.26794/25875671-2018-22-6-157-162

\section{INTRODUCTION}

The Kyrgyz Republic was the first of the Eurasian Economic Union member-states to accede to the World Trade Organization. In recent years, the leadership of the Kyrgyz Republic has been pursuing consistent reform policies on trade facilitation and transition to the international standards implementation.

The international organisations and donors play a significant role in the work conducted in the Kyrgyz Republic. Thus, the major project for the introduction of the information system "Tulpar" - the Single Window Facility in international economic activity - has been introduced in the Kyrgyz Republic with the participation of the UN Economic Commission for Europe, Asian Development Bank, GIZ and other organisations [1].

With the support of the UN Economic and Social Commission for Asia and the Pacific and the Eurasian Economic Commission, some workshops on the further development of the "Single Window" Facility and transition to the cross-border paperless trade have been recently carried out.

The Kyrgyz Republic opportunities as the key points on the Silk Road

The significance of such events for the Kyrgyz Republic increases considering its participation in the global projects of the CPR - "One belt, one road" and in the Eurasian Economic Union projects, such as "Digital Transport Corridors”, “Digital Trade”, “The EAEU Transport Systems" and others.

Considerable analytical work was conducted in the Kyrgyz Republic focused on estimating the current level of implementation of the trade facilitation measures and readiness of the governmental authorities and business to move on to paperless cross-border trade.

Thus, according to the UN global survey on Trade Facilitation and Paperless Trade Implementation, the level of the mentioned measures implementation in Kyrgyzstan constitutes only 37,63\% [2].

According to the World Bank "Doing Business" Index, the Kyrgyz Republic is ranked $84^{\text {th }}$ in the field of "International Trade" in 2018 [3]. It is worth mentioning that the implementation of the relevant reforms al- lowed Kyrgyzstan to move up greatly in the mentioned ranking over the recent years (starting from $183^{\text {rd }}$ in the ranking in 2016).

According to another integrated indicator of the World Bank, namely, the logistic performance index, the Kyrgyz Republic in 2018 is ranked $132^{\text {nd }}$ [4], near African countries and Venezuela.

Besides, it is essential to point out that the level of notification to the World Trade Organization of the provisions of the WTO Trade Facilitation Agreement concerning trade promotion is pretty low [5]. The level of notification of the category A provisions for the Kyrgyz Republic constitutes only 7.6\% [6].

The results of the analysis indicated that the Kyrgyz Republic had a great potential to improve the trade procedures further. The studies had identified the areas for the improvement, in particular, - greater transparency of the government regulation of the international trade activity, facilitation of the government formalities, transfer to the cross-border paperless trade and building the information communication with the key trade partners.

\section{UNECE CAPACITY BUILDING PROJECT}

In response to the indicated problems in the field of regulation and procedural barriers to trade the UN ECE in 2017 launched a project in Kyrgyzstan named "Reinforcement of national capacity of the trade-support institutions" with a special focus on the supply chains management, import and export procedures facilitation and implementation of the "Single Window" Facility.

The authors of the Article participated in the project and by its outcomes indicated the further steps towards the international trade facilitation, which we mentioned in this article.

Within the framework of the aforementioned UN ECE project, there was developed a training course, comprising three modules:

1. Global supply chains.

2. Import, export and transit procedures facilitation.

3. Implementation and promotion of the "Single Window" Facility. 
The training course was intended for the government officials, participating in regulation and control of the foreign trade activity, and economic operators, desiring to enhance their knowledge of international standards, recommendations and best practices in the field of cross-border trade.

The Ministry of the economy of the Kyrgyz Republic supported the holding of training workshops and assisted with the organisation, the invitation of the representatives of the government authorities and business.

Training workshops were conducted in three cities: Bishkek, Osh and Jalal-Abad.

The format of the event entailed both theoretical and practical parts. The attendees of the training workshops participated in the discussions on the topics, completed the questionnaires, learned how to perform the business process analysis and drew up lists of recommendations on the further improvement of import and export procedures.

The information, presented to the attendees in the course of the workshops, was relevant and was generally well perceived and provoked feedback.

The participants of the workshops with knowledge and practical experience in the international trade showed a great interest in the materials presented, took an active part in discussions, gave an assessment of the materials and expressed their wishes and recommendations concerning the materials presented.

It should be further noted that the topic of the workshops raised interest among the scientific community. A large number of educators from the M. Ryskulbekov Kyrgyz Economic University took part in the workshops in Bishkek. The educators assessed the acquired knowledge as crucial for the development of the educational programs and the establishment of new specialisations for the students of the M. Ryskulbekov Kyrgyz Economic University and the trainees of the qualification upgrading programs of the mentioned University.

\section{PROBLEMATIC ISSUES IN INTERNATIONAL TRADE OF THE KYRGYZ REPUBLIC}

In the course of the workshops, the following problematic issues concerning international trade in the Kyrgyz Republic were identified.

1. The lack of concrete and full information on the rules concerning access to the People's Republic of China market.

The attendees highlighted the following problems:

- difficulty in understanding the information published on the information resources of the Peo- ple's Republic of China concerning the rules on the People's Republic of China market access for goods;

- lack of awareness of the requirements imposed by the control authorities of the People's Republic of China for the goods to be imported;

- lack of awareness of the list of documents that should accompany the shipment of goods to the territory of the People's Republic of China;

- difficulty in understanding the procedure for obtaining in the People's Republic of China the documents required to import the goods in the People's Republic of China.

2. Difficult access of Kyrgyzstan's means of transport of economic operators to the territory of the People's Republic of China importing the goods from the People's Republic of China on the territory of the Kyrgyz Republic. In this regard, the vast majority of goods arriving from the People's Republic of China to the territory of the Kyrgyz Republic are imported by the Chinese carriers.

3. The provision of security of goods imported from the People's Republic of China to the Kyrgyz Republic.

Both the quality of goods imported from the People's Republic of China to the Kyrgyz Republic and their safety to human health are to be criticised.

At the same time, the information exchange between the customs authorities of the Kyrgyz Republic and the bodies responsible for the control of quality and safety of products is organised in an unsatisfactory manner.

The customs authorities of the Kyrgyz Republic alone decide whether to allow the goods from the People's Republic of China to enter the Kyrgyz Republic and to be cleared or not. When making such decisions, customs authorities of the Kyrgyz Republic neither inform nor consult with the public authorities of the Kyrgyz Republic responsible for the quality and safety of goods. The goods from the People's Republic of China which do not correspond to the established requirements in respect of quality and safety of products can be identified and removed only while being sold or being a part of goods turnover in the domestic market of the Kyrgyz Republic.

4. Another immediate issue is the information cooperation of the customs and tax authorities within the framework of the Eurasian Economic Union to control the payment of the indirect taxes on imported goods.

One of the challenges for the Kyrgyz Republic is the evasion of payment of the indirect taxes on imported goods. It has been established that some Kyrgyz firms purchase the goods, which have been previously imported into the customs territory of the Eurasian Eco- 
nomic Union, in the Eurasian Economic Union member states, bring the mentioned goods into the territory of the Kyrgyz Republic and sell them to another Kyrgyz firm without paying indirect taxes. After doing so, the mentioned firms terminate their activity.

5. Also, the Kyrgyz exporters have some difficulties in trade with the Eurasian Economic Union member states.

The exporters are not aware of the Eurasian Economic Union Technical Regulation Rules. Therefore, the goods, transported to the territories of the Kazakhstan Republic and the Russian Federation, are not accompanied by the documents needed to confirm the correspondence of the goods to the requirements established in the Eurasian Economic Union.

6. There is no information portal for the exporters and importers in the Kyrgyz Republic, which makes the process of obtaining the up-to-date information concerning the rules on import, export and transit of goods much more complicated.

7. The Kyrgyz exporters did not apply in their practical work importers modern international standards and recommendations on electronic information exchange. They use a paper-based system everywhere. Besides, the significant knowledge gaps, concerning the international standards and recommendations developed by the UN CEFACT, were identified.

\section{STEPS TO UNLOCK THE POTENTIAL OF THE KYRGYZ REPUBLIC}

Based on the results of the training workshops the following recommendations were developed.

There is a recommendation to hold another workshop with more careful and systematic approach to choosing the attendees and compulsory participation of the members of the Council on Facilitation of Trade Procedures in the Kyrgyz Republic.

It has also been suggested to develop a practical guide for the exporters of the Kyrgyz Republic on trade with the People's Republic of China. This practical guide should describe, step by step, all the peculiarities and complex cases of procedures for import to the People Republic of China. Such a guide should be presented in a simple comprehensive form, contain the answers to the most frequently asked questions and also reflect the specificities of work with Chinese counterparts.

There is a need to develop the concise, practical guide on trade with the member countries of the Eurasian Economic Union for the Kyrgyz Republic exporters. We suggest that the compliance with the Technical Regulation norms should be the main focus of such a guide, and the procedure of obtaining the required documents should be thoroughly described.
To solve the problem of the access to the information on the rules governing the foreign trade in goods, we suggest developing a national information portal. The creation of such a portal would encourage the implementation of the Agreement on Trade Facilitation of the World Trade Organization. It would be useful to involve the UNCTAD and the International Trade Centre in this work.

The practical guides mentioned above could be published on such a national information portal.

To strengthen the national capacity of the Kyrgyz Republic and the other Eurasian Economic Union member states in the area of international standards for the international trade facilitation and electronic commerce, it seems appropriate to establish a Regional Training Centre by the Ryskulbekov Kyrgyz Economic University. In close cooperation with the UN ECE, such Training Centre would be able to conduct regular training dedicated to the developed modules for the government officials and business representatives. It would also have an opportunity to promote the UN CEFACT standards and recommendations. In the future, the representatives of the Centre would be able to participate in the UN CEFACT activities, become a support point for the UN CEFACT in the Central Asia Region and provide the methodological, organisational and technical support for the events and researches.

Opening a Training Centre is essential not only for the Kyrgyz Republic, but also for the other Eurasian Economic Union member states and Central Asian countries.

\section{CONCLUSIONS}

Thus, one of the key and effective ways of promoting international trade is building a capacity for state bodies and businesses in the area of international standards and best practices, as well as to increase the availability of information on the rules and requirements of the government regulation of external economic activity, both within the country and in the partner countries.

\section{IT IS REQUIRED TO PROVIDE SYSTEMATIC WORK}

Capacity building requires providing systematic work with state bodies and businesses in all regions of the Kyrgyz Republic. For this, a permanent Regional Training Centre must be created. The M. Ryskulbekov Kyrgyz Economic University will become the base for this centre.

In close cooperation with the leading universities of the Eurasian Economic Union member states and the countries of Central Asia, it is advisable to expand the region of the Regional training centre and to consider the possibility of organising a network model of training programs of the training centre. 


\section{REFERENCES}

1. Kozhankov Yu.A., Bondarenko A.V. Legal and organisational approaches for interagency cooperation and public-private partnership in the Kyrgyz Republic. Tamozhennoe delo = Customs affair. 2011;(3):25-33. (In Russ.).

2. UN Global Survey on Trade Facilitation and Paperless Trade Implementation 2017. URL: https://unnext. unescap.org/content/un-global-survey-trade-facilitation-and-paperless-trade-implementation-2017 (accessed 16.08.2018).

3. The World Bank Economy Rankings Doing Business. URL: http://www.doingbusiness.org/ rankings?region=europe-and-central-asia (accessed 16.08.2018).

4. The World Bank aggregated logistics performance index. URL: https://lpi.worldbank.org/about (accessed 16.08.2018).

5. Kozhankov A. Yu. World Trade Organization Agreement on trade facilitation: prerequisites for adoption and General Characteristics. Vestnik Rossiiskoi tamozhennoi akademii = Bulletin of the Russian Customs Academy. 2016;(4):37-43. (In Russ.).

6. Database of notifications of the provisions of the World Trade Organization's Agreement on trade facilitation. URL: https://www.tfadatabase.org/members/kyrgyz-republic (accessed 16.08.2018).

\section{СПИСОК ИСточнИков}

1. Кожанков Ю.А., Бондаренко А.В. Правовые и организационные подходы в межведомственном взаимодействии и государственно-частном партнерстве в Киргизской Республике. Таможенное дело. $2011 ;(3): 25-33$.

2. Глобальное исследование $\mathrm{OOH}$ по реализации мер содействия торговли и безбумажной торговли. URL: https://unnext.unescap.org/content/un-global-survey-trade-facilitation-and-paperless-tradeimplementation-2017 (дата обращения: 16.08.2018).

3. Рейтинг Всемирного банка Doing Business. URL: http://www.doingbusiness.org/rankings?region=europeand-central-asia (дата обращения: 16.08.2018).

4. Агрегированный индекс эффективности логистики Всемирного банка. URL: https://pi.worldbank.org/ about (дата обращения: 16.08.2018).

5. Кожанков А.Ю. Соглашение Всемирной торговой организации об упрощении торговли: предпосылки принятия и общая характеристика. Вестник Российской таможенной академии. 2016;(4):37-43.

6. База данных нотификаций Соглашения Всемирной торговой организации по упрощению процедур торговли. URL: https://www.tfadatabase.org/members/kyrgyz-republic (дата обращения: 16.08.2018).

\section{ABOUT THE AUTHORS}

Kanybek A. Azhekbarov - Dr. Sci. (Econ.), Honourable professor Ryskulbekov Kyrgyz Economic University, Bishkek, Kyrgyz Republic

ajekbarov@gmail.com

Aleksey V. Bondarenko - Cand. Sci. (Econ.), Associated professor Moscow State Institute of International Relations (University) of Ministry of Foreign Affairs of Russia, Moscow, Russia

bondaralex@list.ru

Anton Y. Kozhankov - Cand. Sci. (Law), Associate professor, Trade Affairs and Trade Regulation Department, Moscow State Institute of International Relations (University) Ministry of Foreign Affairs of Russia, Moscow, Russia; Associate professor, Customs Operations and Customs Control Department of the Russian Customs Academy, Lyubertsy, Russia

tks-2015@yandex.ru

\section{ИНФОРМАЦИЯ ОБ АВТОРАХ}

Каныбек Ажекбарович Ажекбаров - доктор экономических наук, почетный профессор Кыргызского экономического университета им. М. Рыскулбекова, Бишкек, Кыргызская Республика ajekbarov@gmail.com

Алексей Валерьвич Бондаренко - кандидат экономических наук, доцент Московского государственного института международных отношений (Университета) МИД России, Москва, Россия

bondaralex@list.ru 
Антон Юръевич Кожанков - кандидат юридических наук, доцент Московского государственного института международных отношений (Университета) МИД России, Москва, Россия; доцент кафедры таможенных операций и таможенного контроля Российской таможенной академии, Люберцы, Россия tks-2015@yandex.ru

\section{Authors' declared contribution:}

Kanybek A. Azhekbarov - the definition of methods of collection of primary information necessary for the analysis of the current state of international trade procedures of the Kyrgyz Republic, the negotiations with the responsible public bodies and the UN Economic Commission for Europe.

Aleksey V. Bondarenko - studying of development level of this issue in Russian and international academic journals, the analysis of international ratings. The compilation and development of proposals for the further promotion of international trade in Central Asia.

Anton Yu. Kozhankov - the identification of a methodological approach to the study, the identification of positive and negative consequences of trade facilitation and the introduction of a Single Window in the Kyrgyz Republic. The development of proposals for the further promotion of international trade in Central Asia.

Заявленный вклад авторов:

Ажекбаров К.А.- определение методов сбора первичной информации, необходимой для проведения анализа текущего состояния процедур международной торговли Кыргызской Республики, переговоры с ответственными лицами органов власти и Европейской экономической комиссии.

Бондаренко А.В.- изучение степени разработанности данной проблематики в российских и зарубежных исследованиях, анализ международных рейтингов. Обобщение и разработка предложений по дальнейшему содействию международной торговли в Центральной Азии.

Кожанков А.Ю.- разработка методологического подхода исследования, определение позитивных и негативных последствий упрощения процедур торговли и внедрения механизма «единого окна» в Кыргызской Республике. Разработка предложений по дальнейшему содействию международной торговли в Центральной Азии.

The article was received 11.09.2018; accepted for publication 16.11.2018.

The authors read and approved the final version of the manuscript.

Статья поступила 11.09.2018; принята к публикации 16.11.2018.

Авторы прочитали и одобрили окончательный вариант рукописи. 